
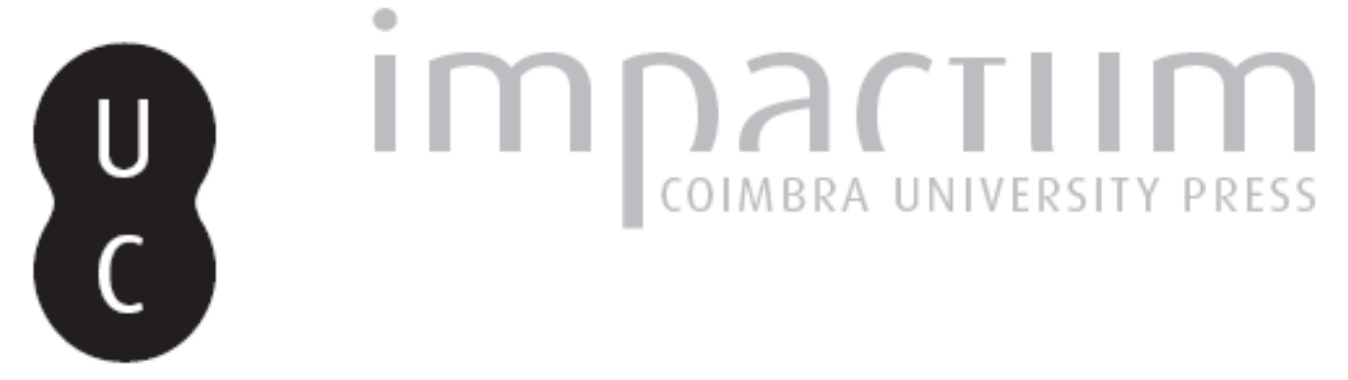

\title{
Recensão e notas de leitura do livro de Karl Kraus (1926) Os Últimos Dias da Humanidade
}

Autor(es): $\quad$ Sheidl, Ludwig

Publicado por: Faculdade de Letras da Universidade de Coimbra

URL persistente:

URI:http://hdl.handle.net/10316.2/40005

DOI:

DOI:https://doi.org/10.14195/0870-4112_2_23

Accessed : $\quad$ 26-Apr-2023 16:08:25

A navegação consulta e descarregamento dos títulos inseridos nas Bibliotecas Digitais UC Digitalis, UC Pombalina e UC Impactum, pressupõem a aceitação plena e sem reservas dos Termos e Condições de Uso destas Bibliotecas Digitais, disponíveis em https://digitalis.uc.pt/pt-pt/termos.

Conforme exposto nos referidos Termos e Condições de Uso, o descarregamento de títulos de acesso restrito requer uma licença válida de autorização devendo o utilizador aceder ao(s) documento(s) a partir de um endereço de IP da instituição detentora da supramencionada licença.

Ao utilizador é apenas permitido o descarregamento para uso pessoal, pelo que o emprego do(s) título(s) descarregado(s) para outro fim, designadamente comercial, carece de autorização do respetivo autor ou editor da obra.

Na medida em que todas as obras da UC Digitalis se encontram protegidas pelo Código do Direito de Autor e Direitos Conexos e demais legislação aplicável, toda a cópia, parcial ou total, deste documento, nos casos em que é legalmente admitida, deverá conter ou fazer-se acompanhar por este aviso.

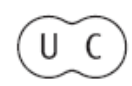


REVISTA DA FACULDADE DE LETRAS U N I VERS I A D E D E C O I M B RA 


\section{Ludwig Sheidl}

Universidade de Coimbra

\section{Recensão e Notas de Leit ura do Livro de Kar I Kr a us (1926) OsÚl timos Dias da Humanidade}

tradução de António Sousa Ribeiro, Edições Antigona, Lisboa 2003.

O autor da tradução não necessita de apresentação: representa a nova geração de Germanistas portugueses, formado pela Escola de Coim bra, onde ainda foi discípulo do Professor Paulo Quintela, é hoje um aca démico com provas dadas que tem também revelado o gosto e o engenho da tradução. Abalançar-se à tradução de uma peça de teatro, cuja extensão - nas palavras de Karl Kraus - "medida à escala terrena daria para preen cher dez serões, destina-se a ser representado por um teatro do planeta Marte" (p. 17)1, é uma prova do que referimos nestes breves traços biográficos do António Sousa Ribeiro.

A tradução do texto dramático está intimamente ligada à dis sertação de doutoramento do tradutor que intitulou Karl Kraus e Shakes peare. Uma Poética de citação.

Quer isto dizer que só um especialista de Karl Kraus, um dos autores satíricos mais marcantes da literatura europeia do século $\mathrm{XX}$, se poderia abalançar - e desde já refiro que com êxito - à tradução de um drama que interessará ,em primeiro lugar, todo o amante da arte literária, neste caso de teatro, mas ainda o estudioso da literatura, em especial da dramaturgia, mas também o historiador e o sociólogo.

O texto teatral, construído em cinco actos, é constituído por 209 cenas - de que o tradutor seleccionou 109 - , abrange o período que vai desde o assassinato político em 28 de Junho de 1914 do herdeiro do trono austro-húngaro Franz Ferdinand em Serajewo na Bosnia, por altura da visita de estado à Sérvia e conclui em 1917, antes do verdadeiro fim das hostilidades.

\footnotetext{
1 Todas as citações se referem ao texto da tradução, com indicação da página.
} 
A tradução das cenas seleccionadas desta peça "incomensurá vel" põe necessariamente muitos problemas, de que destaco os diferentes registos linguísticos na peça. O nosso propósito não é o de apresentar uma mera crítica da tradução: pretendemos apresentar igualmente notas de leitura, tomando por referência os seguintes aspectos: o critério da selec ção das cenas a traduzir e uma problematização do drama, uma análise da tradução propriamente, aspectos formais da versão portuguesa.

\section{A selecção das cenas. Uma problematização da peça.}

O tradutor excluiu o Prólogo, que em nosso entender deveria figurar na tradução, porque apresenta o cenário de referência para a pri meira cena de cada Acto: o picadeiro da avenida central de Viena, a Ringstrasse , onde se situam os palácios, palacetes, as residências de luxo, os ministérios e todo o tipo de repartições públicas, os museus, os teatros e os cafés de referência e não muito distante a chancelaria em (praça) Ballhausplatz e ainda uma estação central- a Estação do Sul, e os muitos figurantes- desde a gente anónima aos grandes detentores do poder eco nómico ou político. No fundo são estes os lugares da acção da peça, quando as cenas decorrem em Viena. O episódio central do Prólogo é a chegada, em comboio especial, dos corpos do casal assassinado.

As personagens são enumeradas no fim do Prólogo: passeantes, transeuntes, criados de café e respectivos frequentadores, policiais, dignatários, sociedade da corte, damas da alta nobreza, clérigos, autarcas, pessoas ilustres, lacaios, jornalistas.

Como se pode concluir o tradutor não introduziu uma lista de personagens, infindável ao longo do drama- em especial tendo em atenção o número de figurantes - variada, ${ }^{\wedge}$ como a própria sociedade do Império Austro-Húngaro, mas que daria um aspecto muito completo do universo retratado.

Para orientação do leitor e certamente de um eventual encena dor a cena de cada Acto apresenta, pela enumeração das personagens, uma indicação do decurso da acção. António Sousa Ribeiro optou por não incluir esta parte do texto na sua tradução, como optou por não incluir a lista de personagens, apresentada no final de cada acto. A composição social das personagens vai variando e reflecte a gradual e inexorável decadência do Império, pondo assim a nu as feridas da guerra, quando as ruas de Viena se começam a encher de soldados estropiados, esgazeados,

Faculdade de Letras i Universidade de Coimbra 


\section{Os Últimos Dias da Humanidade}

de oficiais cada vez mais interessados em manter ou defender os seus estatutos e privilégios, de prostitutas ou marginais, a par de uma socie dade que no meio da calamidade procura manter as aparências.

Do I Acto são-nos apresentadas as cenas indiscutivelmente centrais. As diferentes cenas reproduzem um clima de patriotismo (por vezes exagerado, caricaturado, mas de qualquer modo pouco convin cente), de euforia de guerra (que apesar de tudo se põe ainda em dúvida) mesmo com as primeiras barragens e controle nas estradas do interior do país, os estrategas de café, a mobilização geral e o resultado das "sortes", as primeiras restrições à livre circulação de produtos alimentares, as pri meiras notícias, por testemunhas oculares, da frente russa, enquanto que no quartel-general se faz um primeiro balanço (assustador) das baixas. $\mathrm{Na}$ frente mais protegida os oficiais tiram fotografias a cavalo e ouve-se a referência ocasional de que a guerra vai já no seu primeiro ano.

Para alívio dramático são-nos apresentadas as caricaturas da intelectualidade austríaca que apoia o conflito ou do próprio estadomaior. A prece do papa pela paz e a notícia de milhares de soldados mor tos (de ambos os lados) concluem este primeiro Acto e o primeiro ano de guerra.

As cenas excluídas (num total de dez) não acrescentariam nada de verdadeiramente novo à reconstituição da guerra, antes aprofundariam as contradições inerentes a tão grave conflito. É o caso dos diálogos entre

0 optimista e o eterno descontente, duas figuras que se mantêm ao longo do drama e de que se reproduz apenas um dos quatro diálogos deste

1 Acto.

Somos do parecer que faz falta a tradução da cena intitulada Am Bllhausplatz, sede do governo, onde dois dignatários da corte e do governo comentam a não aceitação do ultimato austro-húngaro por parte da Sérvia, cuja recusa se baseia em dois "pontos sem importância", uma "bagatela" que levou à eclosão da guerra. É também neste tipo de cenas políticas que Karl Kraus é um autor satírico, porque o ultimato a Sérvia era uma intromissão na própria soberania daquele país. Os erros da polí tica austro-húngara nos Balcãs tiveram o seu preço - um preço muito ele vado - e Karl Kraus conhecia-o.

Não vou prosseguir na enumeração de cenas que fariam falta no conjunto da tragédia - como a cena de "uma aula da escola primária" preenchida com uma "lição" de patriotismo - porque toda a selecção implica sacrificar inequivocamente cenas sempre importantes. 
A lista de personagens deste I Acto permite verificar a varie dade dos locais da acção dramática:

Passeantes, transeuntes, mendigos, tratantes, prostitutas, ofi ciais, soldados, manifestantes, clientes e criados de café, ministros, pas sageiros de barco, estudantes nacionalistas alemães, refugiados da Gali cia, séquito de Guilherme I.

Nos II e III Actos passam os três primeiros anos de guerra - se tomarmos por referência a saída da Itália da Tripla Aliança (1916) e o processo num tribunal militar datado de 1917 contra uma mãe solteira que tem um filho de um prisioneiro de guerra francês.

Apresenta-se agora a crise social e o descalabro económico resultante da guerra. Viena está enxameada de refugiados, candongueiros, oficiais de licença ou no comando de um hospital militar, de civis ainda aptos para o serviço militar que conseguiram mover as influências para escapar à mobilização. Nos diálogos está presente a pressão da guerra e pela primeira vez se ouvem vozes de desagrado contra o aliado alemão, o "prussiano". O abastecimento começa a escassear, a entrar em colapso estão há muito em vigor as senhas de racionamento, mas mesmo assim denuncia-se a discriminação das classes sociais : só para os indigentes depois de longas horas de espera numa fila - é que os estabelecimentos estão vazios de bens de primeira necessidade.

Mas o autor tem também informações sobre a situação de calamidade do lado inimigo : a reconstituição de cenas de desespero, de angústia e de revolta numa Belgrado destruída são eloquentes da catás trofe de uma guerra, em que já não há vencedores.

Mas a guerra prossegue : a visita à base de submarinos no Adriático é indício de uma nova escalada.

Também as igrejas - a católica, a luterana, as igrejas protes tantes em geral e a própria igreja islâmica em Constantinopla quebram a neutralidade e incitam ao conflito. As cenas sucedem-se, por vezes muito curtas, mas ilustrativas da degradação também moral da guerra. Conside rando a supremacia do comando militar alemão, algumas cenas tomam por referência o estado maior alemão. Começa a despontar o alvor dos "últimos dias da Humanidade". 


\section{OS Últimos Dias da Humanidade}

Passo a enumerar a lista de personagens destes dois actos :

II Acto (as personagens repartem-se por diferentes lugares geográficos, mas um dos pontos de encontro é o já conhecido corso da Ringstrasse):

Refugiados da Galicia, tratantes, passe antes, transeuntes, mendigos, mendigas, crianças a pedir, oficiais de carreira em licença ou com serviço mais leve na retaguarda, civis que se souberam "arranjar", feridos de todos os graus de gravidade, soldados, actores de província, público, veraneantes, empregados diante de uma mercearia, abastecedores do exército, oficiais, prostitutas, jorna listas, convivas, grupo musical.

III Acto (as personagens distribuem-se pelo palco do conflito mundial, mas Viena não deixa de ser o centro de referência):

Máscaras e lémures, passeantes, transeuntes, mutilados de guerra, cegos, mendigos, mendigas, crianças pedintes, clientes, literatos, liga de Cherus cos em Krems, bailadores, pessoal da justiça, audiência de tribunal, pessoas nas igrejas, oficiais, comensais em restaurantes, povo, soldados, damas de bufete, animadoras de cavalheiros, senhores da Cruz Vermelha, legionários polacos, pessoal de um clube nocturno, actores, orquestra de salão Nechwatal, a orquestra cigana Miskolczy Jancsi.

O IV Acto que decorre no corso da Ringstrasse abre com uma notícia igualmente proclamada pelo ardina sobre "a nota americana de Vilson" (p. 233) :são os célebres 14 pontos anunciados no Congresso em 1918. Os passeantes da média e alta burguesia vivem o quotidiano, ape nas ensombrado pela guerra. Mas Viena continua cosmopolita, ainda que os visitantes estrangeiros sejam sobretudo alemães: fala-se de política e da Aliança austro-húngara e alemã, selada no abraço dos respectivos imperadores.

Mas as cenas mudam mais frequentemente para Berlim. Desta camos a homenagem (satírica) ao general Hindenburg ou o Congresso médico em Berlim. Da ironia trágico-cómica, mais trágica do que cómica, passa- se para a frente de batalha: para a frente de Isonzo (Agosto de 1917), enquanto que no comando da divisão se faz um balanço dos muitos mortos, por falta de uma verdadeira estratégia. A ordem é a de manter a posição até ao "último homem".

Nas famílias burguesas começa a impor-se convicção da supe rioridade da Alemanha: para o Império Austro-Húngaro a guerra está per- 
dida e as consequências políticas são previsíveis depois da proclamação dos 14 pontos do Presidente Wilson. Lançam-se as sementes de una futura integração da Áustria na Alemanha.

As cenas não incluídas na versão portuguesa em nada acres centariam de substancial ao drama humano que se vive. Fará falta a cena 26 (<Semmering) como contraponto austro-húngaro da cena anterior (tra duzida como cena 14 : Almoço com Hindenburg e Ludendorff), em que se refere a possibilidade de uma "paz negociada" (Verständigungsfrieden), proposta primeiro pela Social Democracia alemã em 1916. Mas a política oficial na Alemanha apenas aceita a "vitória final" (Siegfrieden). A figura de Guilherme II foi por diversas vezes caricaturada por Fleinrich Mann, mas dificilmente de forma tão contundente como na cena "Quartel Gene ral Alemão", pondo na boca do Imperador expressões que se aproximam (antecipam?) perigosamente das do ditador do III Reich.

Mais dramáticas são ainda as sevícias e os maus tratos de soldados famintos que procuram meios de subsistência ou que se auto-mutilaram.

O Acto termina com uma conferência de imprensa em que se dá notícia de um ataque de submarinos para gáudio de uma imprensa 'patriotica' e responsável pela distorção da realidade.

$\mathrm{O} \mathrm{V}$ e último Acto retoma as notícias dos jornais, onde se fala de tentativas de paz por parte da Entente. Entretanto a situação de subsis tência das populações atinge o limite. Havia começado a retirada, mas os generais são os primeiros a enriquecer-se com o saque. $O$ exército alemão não foge a esta regra, ainda que se prepare um golpe militar (que só virá a acontecer em Novembro de 1918). Por outro lado o massacre de 180 sol dados alemães pelo comando francês em Verdun é apenas um sinal da massificação da guerra.

As personagens e figurantes do IV Acto dão bem a dimensão da tragédia - também moral - que a guerra exorcizou:

Máscaras e lémures, pas se antes, inválidos, coxos, cegos, mendigos, mendigas, crianças pedindo, fila diante de um guichet de estação, médicos, ofi ciais, tripulação, internados num hospital, vigias, curiosos, frequentadores de cinema, termal istas, frequentadores de clubes nocturnos, cocotes, reconvales centes, feridos de todos os graus, moribundos, membros da sede da imprensa de guerra, música militar, música de clube nocturno.

\section{Faculdade de Letras i Universidade de Coimbra}




\section{OS Últimos Dias da Humanidade}

As personagens e figurantes que se movem no $\mathrm{V}$ Acto dão bem a dimensão do Apocalipse, repetido sem descanso e com todos os meios de destruição neste Grande Teatro do Mundo:

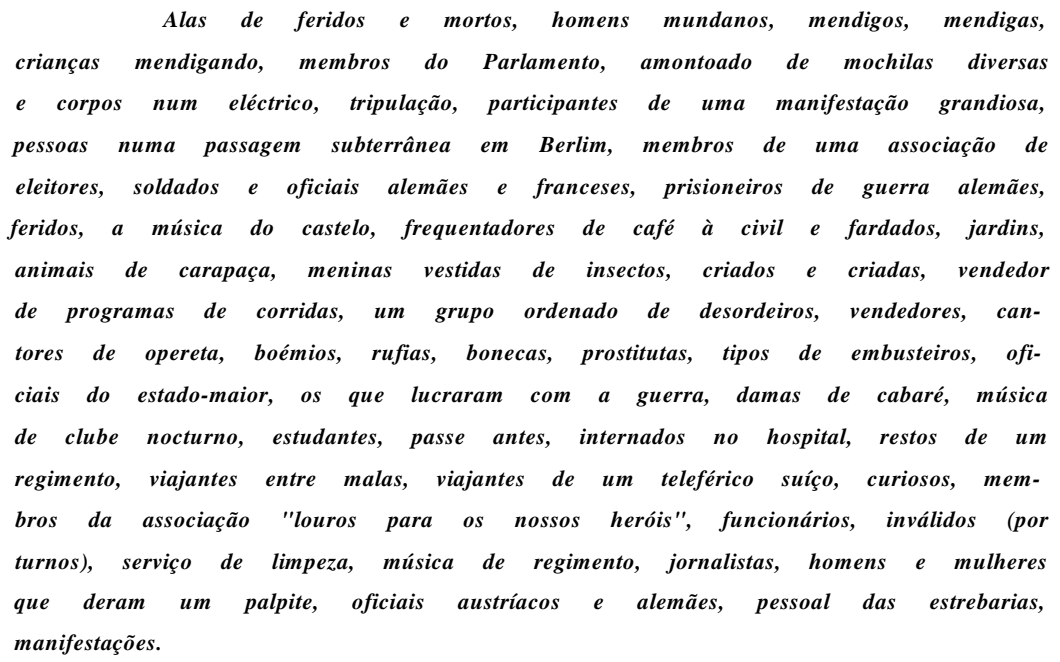

O final aberto do drama bem como a cronologia das cenas são indício das intenções do autor Karl Kraus: o texto dramático não é apenas uma reconstituição histórica - o drama não é um drama histórico em sen tido mais restrito - é na sua concepção muito mais ambicioso. Não pode pois estranhar-se a referência à sucessão do Imperador Francisco José I e pouco depois desta referência ser apresentado em palco um velho senil, homem fraco, incapaz de tomar decisões e preso aos devaneios juvenis .

O drama não tem propriamente um fim, embora as últimas cenas traduzidas se devam compreender como propostas alternativas para o fim do drama.

A cena do Eterno Descontente sentado à secretária (essa figura ficcional que se identifica com o autor dramático) faz um balanço negro da tragédia que está a escrever: "Eu escrevi uma tragédia cujo herói condenado a sucumbir é a humanidade; cujo conflito trágico, o conflito do mundo com a natureza, termina com a morte".(p. 354)

Mas há culpados - cada um que se deixou embalar pela guerra, sem medir as consequências. A enumeração do sofrimento é apenas uma pálida descrição dos muitos quadros que passaram diante dos olhos do espectador. 
Este longo monólogo é, no fundo, um apelo à regeneração do homem. Há que assumir que esta longa guerra com início em Julho/ Agosto de 1914 foi um grande logro em que muitos caíram. E esta é a grande lição deste texto dramático.

Uma outra cena que poderá compreender-se como o final desta tragédia humana é a cena (traduzida e final) do Banquete oferecido pelos oficiais austro-húngaros aos oficiais alemães para comemoração das vitó rias. O discurso do major prussiano, cheio de lugares comuns, de louvor dos bravos soldados, das mães que sacrificaram os filhos à pátria, e em especial da imprensa que na retaguarda mantém a moral, o discurso, ditado por fervor patriótico, é, afinal, uma paródia aos discursos de Gui lherme II. Os inimigos da nação alemã são os anarquistas e os derrotistas - mas a vitória é certa. O potencial inimigo mais poderoso, a Rússia, é só um colosso com pés de barro. O longo discurso termina com uma sauda ção ao Imperador e com um viva (hipócrita) aos aliados.

A discussão entre o major prussiano e o general austro-húngaro sobre o valor do soldado austríaco parece azedar momentaneamente o convívio - mas a orgia continua. As más notícias da frente fazem de novo azedar o convívio, ainda que se invoque sempre a fidelidade dos Nibelungos. As notícias do recuo, da debandada das tropas parece não interfe rir na jovialidade geral. Estes episódios da guerra são, todavia, o prenún cio do fim : os oficiais serão os últimos a percebê-lo. São os represen tantes de uma das classes que lucrou com a guerra- para tanto bastará ter presente a ementa daquele jantar.

O terceiro fim possível para o drama é o Epílogo que António Sousa Ribeiro não integrou (pela sua extensão) na versão portuguesa da tragédia.

Tem como indicação cénica $\boldsymbol{A}$ última noite.

Campo de batalha. Cratera de uma bomba. Nuvens de fumo. Noite sem estrelas. $O$ horizonte é uma parede de chamas. Cadáveres. Moribundos. Apa recem em cena homens e mulheres com máscaras de gás.

É um quadro de horror que culmina no apocalipse e que deverá ser lido/visto como o grande final da sucessão de quadros em os últimos dias da Humanidade.

Um soldado moribundo grita um coral em que recusa morrer pela pátria. Falas córicas do homem e da mulher com máscaras de gás, do general em fuga ou de correspondentes de guerra comentam, como perso 


\section{Os Últimos Dias da Humanidade}

nagens-tipo, à sua maneira, o fim apocalíptico que estão a viver. Depois de um monólogo de breve esperança vão morrendo um soldado grave mente ferido, um soldado cego. Mas a manifestação de sofrimento não tem fim : um novo soldado moribundo amaldiçoa o seu Imperador pelo logro em que caiu. Um nobre enuncia os seus crimes que foi cometendo na carreira de oficial.

Uma mudança de perspectiva faz aparecer em cena um enge nheiro alemão que discursa sobre a "vitória final", tendo de reconhecer os erros da engenharia militar, respeitantes no essencial às armas químicas.

A cena momentaneamente vazia é preenchida pelo coro das hienas- que representam os que verdadeiramente lucraram com a guerra: "Não fomos nós que começámos a guerra / Desejámo-la apenas, mas vós é que partistes." . A parede de chamas ao fundo dá lugar a um brilho de enxofre que encobre o horizonte: aparece uma silhueta gigantesca, o Senhor das Hienas, que vem assistir à parada do seu exército de hienas. A mão esquerda, escondida no bolso, está cerrada em punho, a direita com o indicador esticado, no qual brilha um diamante, aponta para as hienas: apresenta-se como o Anticristo e celebra glorioso o triunfo da morte.

Depois tudo se prepara para a última batalha - são mobilizados os lança-chamas, os canhões e três carros blindados que se lançam para o ataque final - a guerra do Apocalipse, encenada (e aqui o efeito de distan ciamento) por três operadores de cinema. No auge do combate- em que se ouve uma voz (monstruosa) lá de cima e outras vozes cruzadas de baixo , anuncia-se, num mar de chamas e num retumbar de trovões, o fim do mundo, a destruição da Humanidade.

A voz de cima anuncia (impiedosa):

Destruída está a imagem e semelhança de Deus!

Depois de um grande silêncio ouve-se, no meio do apocalipse, como comentário final, a voz de Deus:

Eu não o quis.

No Epílogo enumeram-se as personagens - em parte conhecidas-mas com a intervenção das forças cósmicas esta tragédia de horror tal como no Fausto de Goethe - adquire uma nova amplitude. Está em causa a própria criação do Mundo. Na Idade Média e no Barroco representou-se a queda do Homem. É pois a esta tradição teatral - com a figu ração do Mundo como um grande palco - que Karl Kraus recorre nesta tragédia, para nomear e preservar para a memória dos homens esta tragé dia apocalíptica. 


\section{Ludwig Scheidl}

Cito a propósito o Eterno Descontente (personagem e autor do drama) :"Eu preservo documentos para urna época que já os não irá entender ou para quem este presente é tão longínquo que vai dizer que eu era um falsário." (p. 353)

II- Aspectos formais

O livro abre com um Prefácio - um texto introdutório mas não da autoria do tradutor. Trata-se do célebre Prefácio (muitas vezes citado) de Karl Kraus, mas que para um leitor menos avisado deveria ter sido devidamente identificado.

O tradutor optou por um Posfácio que pelas informações que contém deveria efectivamente estar no princípio do livro para um melhor esclarecimento de leitura. O Posfácio, porque responde à maioria das per guntas que o leitor se coloca, foi escrito mesmo para um leitor atento, mas que precisa de ser orientado, guiado na sua leitura, porque erros de leitura podem destruir irremediavelmente o texto.

Como leitor ocorrem-me várias questões a que o Posfácio só parcialmente responde:

- o tempo da acção dramática.

Refere-se no Posfácio que "uma ou outra referência na pri meira cena de cada um dos cinco actos permite reconstituir uma vaga cronologia da progressão da guerra. A acção vai-se situando num tempo sucessivo, embora, em muitos casos, a cronologia da guerra esteja longe de ser seguida com rigor." (p.442). Somos apesar de tudo do parecer que se poderia ser mais explícito. Logo no Prelúdio o ardina anuncia o assas sinato político do herdeiro do trono do Império Austro-Húngaro e de sua esposa em Serajewo no ano de 1914. Os acontecimentos reconstituídos não vão muito além de 1917; não está em causa proclamar o fim das hos tilidades com a vitória da Entente, está em causa apresentar a primeira chacina sistemática dos tempos modernos - a guerra fratricida que opôs sem um verdadeiro sentido as nações europeias. Somos do parecer que a história da génese e da própria publicação do texto em 1918| 19 e em 1922 motivaram a forma aberta do drama (cf.p.438ss.)

- Sobre o critério da selecção das cenas António Sousa Ribeiro dá algumas indicações no Posfácio: "A forma aberta de Os últimos dias da humanidade permite, com relativa facilidade, cortes substanciais, mesmo que inevitavelmente dolorosos. (...), por outro lado, o trabalho de selecção limitou-se à eliminação de cenas, não se tendo procedido em 
nenhum caso a cortes ou quaisquer outros arranjos no interior de cada cena - todas as cenas seleccionadas foram traduzidas na íntegra" (p.450).

Se não podia estar nos planos do tradutor apresentar uma ver são integral de Os últimos dias da humanidade, somos, todavia, do pare cer que se devia ter incluído o Prelúdio - porque é a partir dele que o drama humano verdadeiramente se inicia com todas as contingências políticas e sociais - e o Epílogo, eventualmente mais alguns diálogos entre o Optimista e o Eterno Descontente (que é de facto um alter-ego de Karl Kraus quando se assume autor do texto). Dos 25 diálogos, apenas foram traduzidos 12, o que consideramos pouco, tanto mais que, como escreve o tradutor no Posfácio :"0 Eterno Descontente (...) é a voz satírica que acom panha a acção do drama, numa função de comentário de carácter córico que vai fornecendo elementos fundamentais de perspectivação" (p.447).

- Sobre o carácter documental do drama permito-me citar do Posfácio: "Na sua estrutura formal Os últimos dias da humanidade repre senta um modelo absolutamente pioneiro de dramas-documento, embora numa acepção muito diferente da que viria a ser associada a este conceito nos anos sessenta". ( p.443.) Quanto aos diálogos não haverá que duvidar da autenticidade da afirmação de Karl Kraus ;’os diálogos mais inverosí meis aqui travados foram pronunciados nesta exacta forma”, (p.444)

A grande fonte documental são as parangonas dos jornais, anunciadas e por vezes deturpadas por um número indeterminado de ardinas, que têm em comum o uso do dialecto vienense. É com um pregão de ardina que tem início a tragédia : "Extraausgabe. Ermordung des Throfolgers! Da Täta vahaftet |Der Täter verhaftet|.

De resto a linguagem é caracterizada por António Sousa Ribeiro : "Não se trata apenas do registo coloquial, omnipresente, e que é um dos principais meios ao serviço do subtil jogo de contrastes entre o cómico e o patético, mas também dos dialectos, a começar, evidente mente, pelo dialecto vienense, mas com uma presença importante do dia lecto berlinense e, sobretudo, do jargão dos judeus austríacos, caracterís tico de camadas sociais oriundas do Leste e insuficientemente assimila das". (p. 448) Mas os dialectos variam conforme a origem geográfica. Recordo a primeira cena fora de Viena a decorrer no Tirol : as persona gens falam necessariamente o dialecto tirolés. Karl Kraus, também actor, conhecia bem as nuances de linguagem, que não são um aspecto menor para a própria caracterização das personagens. Também a nobreza, edu cada no chamado alemão da corte (Schönbrunnerdeutsch), quando o diá logo se inflama retoma o falar vienense. 
- Referir-me-ei por último à tradução em si. Considerando os inúmeros problemas linguísticos a resolver - desde o falar dialectal ou regional, ao jargão político e militar do tempo (hoje em grande parte caído em desuso ou "esquecido") a caricatura dos nomes próprios mediante a composição/aglutinação de conceitos, nomes ou títulos (uma arte em que o autor satírico Karl Kraus era mestre) - António Sousa Ribeiro seguiu os ensinamentos do seu mestre (que foi um grande tradutor de Shakespeare para alemão) como regista no Pósfácio: "Mas o acto de tradução, como propõe o próprio Kraus através de um - intraduzível trocadilho, joga-se na transmutação do verbo 'übersetzen' ('traduzir') na fórmula imperativa 'üb' 'ersetzen!' ('aprende a substituir!'). O seu crité rio de validade decisivo há-de ser sempre o da forma dessa substituição, isto é, há-de medir-se pela obtenção ou não de equivalências adequadas na língua de chegada", (p.449)

No que respeito ao conteúdo da tradução posso afirmar que do confronto textual se não encontram imprecisões ou incorrecções. Há mesmo passos de grande imaginação e acribia do tradutor, passos que se integram perfeitamente no conjunto do texto. Não quero significar com esta afirmação que não poderia haver propostas alternativas - qualquer leitor atento poderia apresentar propostas de tradução diferentes - mas o que está em causa é o todo da tradução como texto a ser posto em palco.

Também neste aspecto - o mais difícil para qualquer tradutor deste texto dramático - há que louvar a tradução de António Sousa Ribeiro que encontra as palavras certas para o eventualmente intraduzível.

A última guerra fratricida da Europa que a História regista começou em 1914 e prolongou-se de forma cada vez mais destrutiva até Novembro de 1918, para ser retomada de forma ainda mais feroz em 1939.Verdade é também que no auge do primeiro conflito se ouvem vozes de um ressurgimento da Europa, como as palavras quase proféticas de Hugo von Hofmannsthal :

"Não me parece que a tarefa deva constar em repor a Europa dos últimos decénios com as suas asas meio paralisadas, sou antes de opinião que esta missão tem de ser compreendida de forma mais elevada"2.

\section{Faculdade de Letras i Universidade de Coimbra}




\section{OS Últimos Dias da Humanidade}

E em 1942, um grupo de jovens estudantes de Munique, que intitulou o seu movimento de Rosa Branca, teve a veleidade de se assumir como força capaz de se opor ao NS na Alemanha do III ou do Grande Reich Alemão, anunciando no seu último panfleto, lançado das escadarias da Universidade de Munique :

"O nome alemão ficará ultrajado para sempre, se a juventude alemã se não erguer finalmente, para vingar e expiar simultaneamente, destruir os seus opressores e construir uma nova Europa espiritual"*3.

E o que parecia impossível aconteceu: a pacificação das nações e a superação dos nacionalismos europeus com o estabelecimento da Comunidade do Carvão e do Aço, sancionada pelo Tratado de Romaorigem remota da União Europeia.

Duas guerras fratricidas, fixadas nos seus horrores e contradi ções por Karl Kraus em Os últimos dias da humanidade (Die letzten Tage der Menschheit) e, numa escala mais reduzida, por Wolfgang Bordiert no drama Lá fora diante da porta (Draussen vor der Tür) são testemunhos que cada um de nós tem de ter sempre presentes para estarmos a salvo de qualquer calamidade no futuro.

Creio pois que a actualidade da tragédia de Karl Kraus reside afastados os fantasmas da violência - na síntese final de Antonio Sousa Ribeiro no seu Posfäcio :

"A actualidade de Os últimos dias da humanidade não reside, de facto, apenas na sua portentosa diatribe antimilitarista e no odio abso luto contra a guerra (Canetti) que ela inspira. Reside (...) na agudeza do olhar impiedoso sobre esse estado de coisas, um olhar sismográfico tão sensível aos sintomas da catástrofe como desperto para a possibilidade de salvação(...)".(p. 451)

Só esta certeza pode justificar as muitas centenas de diálogos de sofrimento e de dor ou de traços de escárnio com que os privilegiados procuram salvar a pele, só a certeza de que "para além da desesperança nasce a esperança" (Thomas Mann) "legitima a arte literária de nomear o inominável.".

Concluo com um agradecimento muito sincero a António de Sousa Ribeiro por ter trazido para a língua portuguesa um dos textos mais importantes do nosso passado comum, referência para todo o defensor da verdadeira fraternidade entre os homens.

Dagbladet apud H. v.Hofmannsthal, Prosa III (S. Fischer Verlag, Frankfurt am Main 1952) 503.

3 Die weisse Rose, 3. und letztes Flugblatt. 